XIX.

Aus der I. inneren Abtheilung des städtischen Krankenhauses Charlottenburg-Westend (Prof. Dr. Umber).

\title{
Beiträge zur Chemie des Blutes in Krankheiten mit besonderer Berücksichtigung der Lipoide.
}

\author{
IV. Mittheilung: \\ Diabetes und Lipämic. \\ Von \\ Dr. H. Beumer und Dr. M. Bürger.
}

Sicher weit häufiger als früher angenommen wurde ${ }^{1}$ ), findet sich in Fällen von schwerem Diabetes die als Lipämie bezeichnete Blutveränderung. Gewöhnlich ist sie allerdings nicht so hochgradig ausgeprägt, dass man sie direct beim Aderlass oder gar beim Augenspiegeln erkennt, sonders wird erst sichtbar, nachdem sich die Blutkörperchen durch Stehen oder Centrifugiren gesenkt haben und das Serum alsdann als völlig undurchsichtige weisse Rahmschicht darüber steht. Es giebt Seren mit sehr hohem Fettgehalt wie z. B. Seren bei Icterus mit bis zu $22 \mathrm{pM}$. ätherlöslichem Extract, die völlig klar und durchsichtig sind. Bei der Lipämie - nicht bei alimentärer Lipämie - wird die Trübung ebenso wie bei den chylösen Exsudaten durch eine Lipoid-Eiweissverbindung hervorgerufen und das Serum lässt sich durch ein einfaches Ausschütteln mit Aether allein nicht klären. Chemiseh charakterisirt sich die diabetische Lipämie durch eine Vermehrung nicht nur des Fettes, sondern auch der Lipoide Cholesterin und Lecithin, sodass dieser Zustand nach Klemperer und $\mathrm{H}$. Umber besser als Lipoidämie zu bezeichnen ist. Klemperer und H. Umber ( 1 ) fanden unter 9 Fällen von diabetischer Acidosis 8 Fälle mit Lipämie. Auch wir konnten bei 7 Fällen von schwerem Diabetes fünfmal Lipämie constatiren, während ein jugendlicher Diabetes und ein im Coma zu Grunde gegangener Diabetiker keine Lipämie zeigte (s. Tabelle). Diese Befunde sprechen jedenfalls für ein sehr bäufiges $\mathrm{Zu}$ sammengehen von Acidosis and Lipäroie und es soheint aush wirklich ein gewisses Abhängigkeitsverhältniss der Lipämie von dem Grade der Acidosis zu bestehen. XIX und XIV stellen solche Fälle dar, bei denen

1) Wenn Hegler an seinem Eppendorfer Material unter 180 Diabetesfällen nur 2 mal Lipämie findet (Mïnchener med. Wochenschr., 1913, No. 16), können wir uns das nur dadurch erklären, dass er bei seinen Fällen keine Trennung von Blutkörperchen und Serum vorgenommen hat, wodurch erst in Iejchteren Fällen die Lipämie zu Tage tritt. 
$1000 \mathrm{~g}$ Serum enthalten 1 ):

\begin{tabular}{|c|c|c|c|c|c|c|c|c|}
\hline & $\begin{array}{c}\text { ätherlos- } \\
\text { lichen } \\
\text { Extract }\end{array}$ & Lecithin & $\begin{array}{l}\text { freies } \\
\text { Chole- } \\
\text { sterin }\end{array}$ & $\begin{array}{l}\text { Chole- } \\
\text { sterin- } \\
\text { ester }\end{array}$ & $\begin{array}{l}\text { Fett- } \\
\text { säuren }\end{array}$ & $\begin{array}{l}\text { Trocken- } \\
\text { Substanz }\end{array}$ & Eiweiss & $\mathrm{Fe}$ \\
\hline $\begin{array}{l}\text { XIV. Leichter Alters- } \\
\text { diabetes, } 70 \text { jähr. Mann, } \\
\text { Arteriosklerose }\end{array}$ & 7,070 & 1,437 & 0,357 & 0,279 & - & 96,730 & 74,182 & $\ldots$ \\
\hline $\begin{array}{l}\text { XV.Coma diabeticum,Aci- } \\
\text { dosis, Lipämie, } 17 \text { jähr. } \\
\text { Mädch., i.Coma gestorb. }\end{array}$ & 27,954 & 3,251 & 1,661 & 3,146 & $\stackrel{-2}{-196}$ & 108,179 & $56, \geq 05$ & - \\
\hline $\begin{array}{l}\text { XIX. Schwerer Diabetes, } \\
\text { Acidosis, 25jähr. Frau, } \\
\text { keine Lipämie }\end{array}$ & 9,739 & 4,514 & 0,728 & 2,338 & 1,522 & 83,246 & 62,534 & - \\
\hline $\begin{array}{l}\text { XXIV. SchwererDiabetes, } \\
\text { Acidosis, Lipämie, } \\
\text { 30jährige Frau }{ }^{2} \text { ) }\end{array}$ & 33,376 & 5,571 & 1,441 & 4,450 & 1,452 & 117,094 & 68,851 & 一 \\
\hline $\begin{array}{l}\text { XXX. Mittelschwerer Dia- } \\
\text { betes, keine Acidosis, } \\
\text { Lipämie, } 50 \text { jähr. Mann }\end{array}$ & 18,337 & 3,460 & 0,919 & 3,204 & 1,182 & - & - & - \\
\hline
\end{tabular}

$1000 \mathrm{~g}$ Erythrocyten enthalten:

XIV. Leichter Altersdiabetes, 70 jähr. Mann, Arteriosklerose

XV.Coma diabeticum, Acidosis, Lipämie, 17 jähr. Mädch.,i.Coma gestorb.

XIX. Schwerer Diabetes, Acidosis, 25 jähr. Frau, keine Lipämie

XXIV. SchwererDiabetes, Acidosis, Lipämie, 30jährige Frau

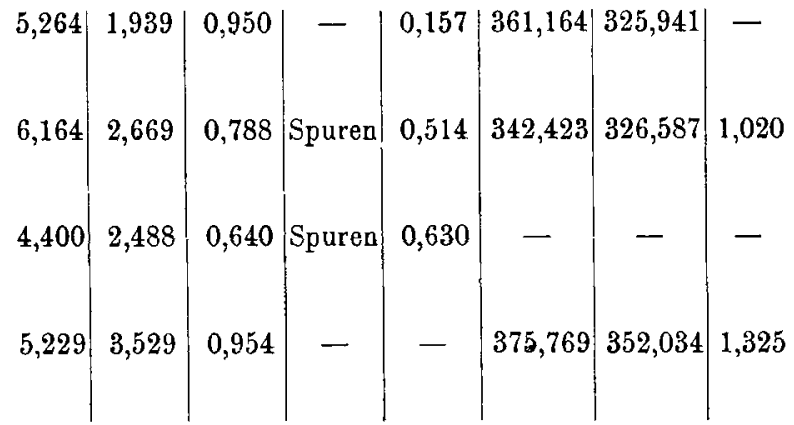

mit einer erheblichen Acidosis eine ausgeprägte Lipämie bestand. Bei XIX war nach drei Hafer- und einem Gemüsetag die Linksdrehung von 0,3 auf 0,0 (von 15,8 auf $0,0 \beta$-Oxybuttersäure) gesunken, zugleich die manifeste Lipämie verschwunden, das Serum vollkommen klar und die oben angeführten Zahlen zeigen nur einen wenig erhöhten Fettgehalt des Serums. Aulfallend ist das Fortbestehen einer deutlichen Cholesterämie - die Cholesterinwerthe betragen das Dreifache der Norm - woraus

1) Bezüglich der Untersuchungstechnik ef. unsere frühere Mittheilung.

2) Mit Rücksicht auf die Rolle, die Wa oker und Hueck (Zeitschr. f. phys. Chem., 1913, Bd. 71) den Nebennieren im Cholesterinhaushalt vindiciren, mögen hier die Cholesterinwerthe der Nebennieren dieses im Coma verstorbenen Falles angeführt werden:

Gewicht der Nebennieren feucht $13,3 \mathrm{~g}$ trocken $4,096 \mathrm{~g}$ freies Cholesterin $0,017 \mathrm{~g}$ Cholesterin als Ester $0,113 \mathrm{~g}$

Die Zahlen entsprechen ungefähr der Norm, eine pathologische Verminderung, wie sie Kawamura (Die Cholesterinesterverfettung. Fischer. Jena 1911) in seinen Diabetesfällen fand, liegt in diesem uncomplicirten Fall von Coma diabet. nicht vor. 
hervorgeht, dass sich der Körper entweder des Cholesterins und seiner Ester nur langsam and schwer entledigen kann - über die Ausscheidung des Cholesterins ist ja noch nichts Sicheres bekannt - oder aber es bleibt gewissermaassen eine verkappte Lipämie bestehen, die beim Steigen der Acidosis leicht wieder zur manifesten Lipämie führen kann. Bei XXIV wurde das Blut während der Lipämie untersucht, nach einer diätetischen Einstellung war die Acidosis sehr gesunken und auch zugleich die Lipämie verschwunden.

Bei den engen Beziehungen zwischen Acidosis und Lipämie wurde häufig der Versuch gemacht, ihr Auftreten aus denselben Ursachen herzuleiten, die eine Acidosis herbeiführen, oder sie mit den durch die Acidosis gegebenen Verhältnissen im Stoffwechsel in Zusammenhang zu bringen. Zumal die Auffassung, in der Lipämie nur den Ausdruck eines rückläufigen Fetttransportes aus den Fettdepots zu den Verbrennungsstätten des Körpers zu sehen, nicht ausreichend und die reiche Vermehrung der Lipoidsubstanzen einen gleichzeitigen Zellzerfall zu fordern schien, lag es nahe, an einen unmittelbaren Zusammenhang mit der Acidosis zu denken. Denn dass der acidotische Organismus zwecks Erschliessung neuer Zuckerquellen auch sein eigenes Eiweiss zugleich mit dem Fett angreift, scheint nach den neueren Anschauungen über die Zuckersynthese im Körper aus Fett und Eiweiss doch ziemlich wahrscheinlich. Der erhöhte Eiweisszerfall braucht dabei nicht nothwendiger Weise in der N-Bilanz in Erscheinung zu treten [partieller Eiweissabbau F. Umber's (2), Falta (3)]. Das noch nicht geklärte Auftreten von Kreatin im Urin, das auch in unseren Fällen sich zeigte, kann im Sinne erhöhten Zellzerfalls gedeutet werden. Der hohe Gehalt des Serums an Cholesterinestern macht ein vorausgehendes Freiwerden von Fettsäuren wahrscheinlich, wie dies auch bei anderen regressiven Veränderungen gefunden wurde (Atheromatose der Aorta). Klemperer und H. Umber berechnen alles gefundene Cholesterin als Ester. Aus unseren Zahlen geht hervor, dass ein nicht unbeträchtlicher Antheil in Form freien Cholesterins vorbanden ist.

B. Fischer (4) fand, dass sich der Fettgehalt des lipämischen Blutes nach wochenlangem Stehen nicht änderte, dagegen nach Zusatz von normalen rothen Blutkörperchen eine erhebliche Verminderung erfuhr. Er glaubte daher die Ursache der Lipämie in einem erloschenen Fettspaltungsvermögen des Blutes gefunden zu haben. Wahrscheinlich gemacht wurden diese Befunde durch die Feststellung Konnstein's und Michaelis' (9), die ein lipolytisches Ferment der rothen Blutkörperchen gefunden zu haben glaubten, das also den Blutkörperchen bei der Acidosis fehlte. Klemperer und H. Umber konnten die Versuche Fischer's, Konnstein's und Michaelis' (5) nicht bestätigen und führen sie auf Mitwirkung von Bakterien zurück. Auch wir konnten durch eine Versuchsanordnung, bei der wir lipämisches Serum einerseits mit den dazugehörigen Blutkörperchen, andererseits mit den Blutkörperchen eines normalen Menschen 24 Stunden im Brutschrank digerirten, kein Schwinden des Fettgehalts constatiren. Ein Eingehen auf die Serolipase Hanriot's, 
die auch zur Erklärung der Lipämie herangezogen wurde, erübrigt sich nach den Feststellungen Doyon's und Morel's (6).

Soweit wir orientirt sind, gingen die in der Literatur niedergelegten Fälle von diabetischer Lipämic stets mit einer Acidosis einher, sodass Schwarz dies Verhalten sogar so formulirt hat: keine diabetische Lipämie ohne Acidosis. Dass dies nur bedingt richtig ist, zeigt unser Fall XXX, der einen mittelschweren Diabetes ohne eine Spur von Acidosis darstellt. Hier war das Serum ganz milchweiss und ist, wie die Tabelle zeigt, auch in seiner chemischen Zusammensetzung nicht von den anderen diabetischen Lipämien zu unterscheiden. Der Verdacht, es könne sich um eine alimentäre Lipämie handeln, wurde durch zwei Blutentnahmen in nüchternem Zustand am Morgen ausgeschaltet. Da der Mann zuverlässig nur ein sehr mässiges Potatorium angiebt, ausserdem seit 14 Tagen alkoholfrei gelebt hat, wäre die Annahme, im Potatorium die Ursache sowohl für den Diabetes, als auch für die Lipämie zu erblicken, nur sehr gezwungen. Es muss daher gesagt werden, dass, wenn auch die meisten diabetischen Lipämien von einer Acidosis begleitet sind, es doch auch seltene Fälle giebt, bei denen eine einwandfreie Lipämie ohne Acidosis besteht. Die Erklärung für das Zustandekommen der diabetischen Lipämie wird hierdurch nicht erleichtert. Eine weitere Stütze dafür, dass die diabetische Lipämie nicht unter allen Umständen an das Auftreten von Acetonkörpern im Urin gebunden ist, bot uns die Beobachtung eines schwer diabetischen Mannes mit ausgesprochener Acidosis, Kreatinurie und schwerer Jipämie. Es gelang durch diätetische Maassnahmen (kohlehydratfreie Einstellung, $100 \mathrm{~g}$ Hediosit pro die an 7 aufeinanderfolgenden Tagen), den Patienten für die Dauer von 5 Tagen zucker- und acidosefrei zu machen. Trotzdem war bemerkenswerther Weise am Morgen des 5. Tages noch eine schwere Lipämie vorhanden. Es ist das zugleich ein Beweis dafür, dass trotz der Zucker- und Acidosefreiheit des Urins schwere diabetische Stoffwechselstörungen weiterbestehen bleiben können.

Auch das Verhalten der Blutkörperchen in einem so lipoidreichen Serum war uns von Interesse zu untersuchen. Aus der Tabelle ist ersichtlich, dass der Jipoidgehalt der Blutkörperchen ziemlich unbeeinflusst geblieben ist. Sicher besteht keine Verminderung des Lecithingehaltes der Blutkörperchen, wie sie von Erben beschrieben worden ist. Mit anderen Untersuchern finden wir eine Eindickung der rothen Blutkörperchen, wie aus den hohen Trockensubstanzwerthen hervorgeht, die umsomehr für eine Eindickung sprechen, als der Volumquotient und die Zahl der Blutkörperchen im Sinne einer Anämie herabgesetzt waren. Also nehmen auch die Blutkörperchen an der bei Diabetes stattfindenden Wasserverarmung der Gewebe theil.

Bei XIX und XXV wurden Spuren von Cholesterinestern in den Blutkörperchen gefunden.

Das Verhalten dieser Blutkörperchen zeigt aufs Neue die schon von Hoppe-Seyler (7) hervorgehobene Thatsache, in wie hohem Grade die Zusammensetzung der Blutkörperchen von dem des umgebenden Serums unabhängig ist. Dies trifft sowohl für den Fett-, 
Eiweiss- und Wassergehalt zu. Ein vermehrter Jecithin- und Cholesteringehalt des Serums braucht durchaus nicht mit einem Schwund und einer Verarmung an diesen Substanzen in den Blutkörperchen einherzugehen.

\section{Literatur.}

1) S. Klemporer und H. Umber, Arch. f. klin. Med. 1908.

2) F. Umber, Therapio der Gegenwart. 1901.

3) Falta, Zeitschr f. Klin. Med.

4) B. Fiscber, Virchow's Arcbiv. Bd. 172.

5) Konnsacin ma Michaglis, Erggba, d, Phys. 3. Jahrg. 1.

6) Doyons und Morel, Compt read. de la soc. biol 1902.

7) Hoppo-Seyler, Med,-cher. Unters. 1866. 